\title{
Boży wojownicy czy pobożni pielgrzymi? Polacy i ich wyprawy do Ziemi Świętej na marginesie książki Agnieszki Teterycz-Puzio, Polscy krzyżowcy. Fascynująca historia wypraw Polaków do Ziemi Świętej, Wydawnictwo Poznańskie, Poznań 2017, ss. 368
}

Fenomen ruchu krucjatowego, który zrodził się w XI stuleciu, zajmuje szczególne miejsce w badaniach współczesnej mediewistyki. Poświadcza to wielość opublikowanych prac zwłaszcza na gruncie historiografii powszechnej ${ }^{1}$. Historia wypraw krzyżowych do Ziemi Świętej w obronie chrześcijan, które przypadały na lata 1095-1291, budzi wśród badaczy zainteresowanie z racji swej specyfiki łączącej elementy dwóch istotnych zjawisk w średniowieczu, tj. świętej wojny/wojny sprawiedliwej oraz ruchu pielgrzymkowego.

W polskiej historiografii tematyka wypraw krzyżowych oraz ich oddziaływania na społeczeństwo polskie zostały przedstawione niewyczerpująco. Wynika to przede wszystkim z niewielkiej ilości zachowanych relacji, zarówno w źródłach rodzimych, jak i obcych. Jednakże powstało kilka prac, w których autorzy zdecydowali się poruszyć ową tematykę w odniesieniu przede wszystkim do stosunku władców polskich wobec idei krucjatowej i ich zaangażowania w obronę wiary chrześcijańskiej. Wymienić należy m.in. publikacje takich autorów, jak: Mikołaj Gładysz, Andrzej Grabski, Jerzy Grygiel, Stanisław Aleksander Korwin, Maria Starnawska i Agnieszka Teterycz-Puzio².

1 Zob. A. De la Croix, Templariusze. W sercu wypraw krzyżowych, przekł. I. Kasperska, Poznań 2006, ss. 328; M. Haag, Tragedia templariuszy: powstanie i upadek państwa krzyżowców, przekł. A. Bukowczan-Rzeszut, Kraków 2016, ss. 360; T.F. Madden, Historia wypraw krzyżowych: nowe ujęcie, tłum. A. Czwojdrak, Kraków 2008, ss. 313; M. Walsh, Wojownicy Pana. Chrześcijańskie zakony rycerskie, przekł. T. Karłowicz, Kraków 2005, ss. 265.

2 Zob. M. Gładysz, Zapomniani krzyżowcy. Polska wobec ruchu krucjatowego w XII i XIII wieku, Warszawa 2002, ss. 374; idem, W sprawie udziału polskiego księcia w II krucjacie jerozolimskiej (1147-1149), w: Krzyżowcy, kronikarze, dyplomaci, red. B. Śliwiński, „Gdańskie Studia z Dziejów Średniowiecza", nr 4, Gdańsk-Koszalin 1997, s. 33-52; A. Grabski, Polska w opiniach obcych XI-XIII w., Warszawa 1964, ss. 414; J. Grygiel, Jaksa z Miechowa i inni. Udział Polaków w wyprawach krzyżowych do Ziemi Świętej, w: Ziemia miechowska w dziejach Polski. Dziedzictwo i perspektywy, red. A. Waśko, Kraków 2006, s. 11-22; S.A. Korwin, Stosunki 
Niewątpliwie krucjaty rycerstwa europejskiego do Ziemi Świętej początkowo były przedsięwzięciem militarnym wznieconym przeciwko islamskim Turkom seldżuckim ${ }^{3}$, jednakże w kolejnych dwóch wiekach przeobraziły się $\mathrm{w}$ ruch pielgrzymkowy, szczególny wyraz religijności wędrujących pątników. Warto podkreślić, że do najczęściej odwiedzanych wówczas loca sacra należały: Rzym, Compostela, a nade wszystko Jerozolima, którą zwano sercem świata chrześcijańskiego ${ }^{4}$. Niniejszy artykuł ma na celu przedstawienie recenzowanej pracy, jak i w jeszcze większym stopniu odpowiedzenie na zasadnicze pytania: Czy polscy uczestnicy wypraw do Ziemi Świętej inspirowali się wezwaniem papieskim do walki z niewiernymi prześladowcami chrześcijan bądź ich motywów należy doszukiwać się przede wszystkim w wymiarze praktyki religijnej? A także czy publikacja Pani Agnieszki Teterycz-Puzio wnosi pewne novum w tematyce krucjatowej na karty polskiej historiografii?

Autorką recenzowanej książki jest Agnieszka Teterycz-Puzio, doktor habilitowany nauk humanistycznych z zakresu historii średniowiecza, profesor nadzwyczajny Instytutu Historii i Politologii Akademii Pomorskiej w Słupsku. Autorka skupia swoje zainteresowania badawcze wokół dziejów książąt i możnowładców okresu rozbicia dzielnicowego w Polsce, co znajduje potwierdzenie w wielu publikacjach naukowych ${ }^{5}$.

Cel badawczy recenzowanej pracy został przez Autorkę jasno określony. Po pierwsze, starała się ona ustalić, jakimi motywami kierowali się podróżnicy z ziem polskich, udając się do Ziemi Świętej. Następnie prześledziła możliwe szlaki lądowe i wodne, które mogli przemierzać. I wreszcie podjęła próbę odtworzenia najczęściej odwiedzanych miejsc świętych na podstawie geografii sakralnej Ziemi Świętej, ze szczególnym uwzględnieniem Jerozolimy. Ramy chronologiczne pracy Polscy

Polski z Ziemiq Święta, Warszawa 1959, ss. 261; M. Starnawska, Między Jerozolima a Łukowem. Zakony krzyżowe na ziemiach polskich w średniowieczu, Warszawa 1999, ss. 416; A. Teterycz-Puzio, Henryk Sandomierski polski krzyżowiec (1126/1133-18 X 1166), Kraków 2015, ss. 166; eadem, Polscy krzyżowcy. Fascynująca historia wypraw Polaków do Ziemi Świętej, Poznań 2017, ss. 368.

3 M. Haag, op. cit., s. 92-102; T.H. Madden, op. cit., s. 7.

4 Ze względu na szczególny charakter religijny Jerozolimy, Rzymu oraz Composteli, pielgrzymki do tych miejsc uznano za peregrinationes maiores (pielgrzymki większe, ważniejsze), co zostało zatwierdzone przez Stolicę Apostolską. Por. H. Manikowska, Jerozolima - Rzym - Compostela. Wielkie pielgrzymowanie u schyłku średniowiecza, Wrocław 2008, s. 5-6.

5 A. Teterycz-Puzio, Na rozstajnych drogach. Mazowsze a Małopolska w latach 1138-1313, Słupsk 2012; eadem, Piastowskie księżne regentki (koniec XII w. - pocz. XIV w.). O utrzymanie władzy dla synów, Kraków 2016, ss. 285; eadem, Urzędnicy sandomierscy w okresie rozbicia dzielnicowego - geneza, znaczenie, kompetencje, "Słupskie Studia Historyczne" 2000, 8, s. 39-63; eadem, Zjazdy ksiażąt oraz możnych małopolskich i mazowieckich w I połowie XIII w. (Ze stosunków małopolsko-mazowieckich), „Studia Historyczne” 2005, 48, 3-4, s. 267-292. 
krzyżowcy. Fascynujaca historia wypraw Polaków do Ziemi Świętej obejmują okres od XII w. do XV w. Wskazują na to chociażby poszczególne tytuły rozdziałów. Jednakże w ostatnim rozdziale Autorka pokusiła się o krótkie przedstawienie przykładów pielgrzymek do Ziemi Świętej Polaków z początku XVI stulecia. Ponadto istnieje pewna nieścisłość, gdyż Autorka we Wstępie pisze:

Średniowieczne podróże do Ziemi Świętej, ogłaszane w XII i XIII w. oraz pod koniec średniowiecza, które przybrały charakter zbrojnych wypraw, czyli krucjat, należy uznać także za specyficzną formę pielgrzymowania. Były one bowiem połączeniem zjawiska pielgrzymki (podejmowanej dla odprawienia modłów, zdobycia łask itp.) oraz świętej wojny (rozpoczynanej dla odbicia Ziemi Świętej z rąk muzułmanów i jej ochrony)6.

W tym przypadku warto dostrzec, że wezwania krucjatowe pojawiły się już w XI stuleciu. Autorka wspomina przecież na późniejszych stronach recenzowanej publikacji chociażby o synodzie w Clermont z $1095 \mathrm{r}$. i powszechnie znanym wezwaniu do wypraw krzyżowych papieża Urbana $\mathrm{II}^{7}$. Idąc dalej i jeszcze wcześniej, można napomnieć o intencjach papieża Grzegorza VII (pontyfikat od 1073 r. do 1085 r.), który na prośbę cesarza bizantyńskiego próbował zorganizować wyprawę przeciw Turkom, ale przez spory w Europie związane z inwestyturą ostatecznie z niej zrezygnował ${ }^{8}$. Stąd zaskakuje przesunięcie we wspomnianym Wstępie początkowej ramy chronologicznej na XII w. Tym bardziej że w odniesieniu do ziem polskich nie można jednoznacznie stwierdzić czy pod koniec XI stulecia idea krucjatowa była obca przedstawicielom państwa polskiego, gdyż zasób źródeł jest mały, a wzmianki o początku krucjat lakoniczne, co podkreśla chociażby Mikołaj Gładysz ${ }^{9}$. Przykładowo, zachowała się adnotacja pod 1099 r. w Roczniku Kapituty Krakowskiej o zdobyciu przez chrześcijan Jerozolimy: „Jerusalem a Christianis capta est”"10. M. Gładysz zwraca również uwagę na polskie kontakty z ważnymi ośrodkami ruchu krucjatowego, takimi jak Lotaryngia i Prowansja ${ }^{11}$.

\footnotetext{
$6 \quad$ Eadem, Polscy krzyżowcy, s. 7.

7 Ibidem, s. 28.

8 M. Haag, op. cit., s. 86-88.

9 M. Gładysz, Zapomniani krzyżowcy, s. 26-27.

10 Rocznik Kapituty Krakowskiej, w: Monumenta Poloniae Historica [dalej: MPH], t. V, wyd. Z. Kozłowska-Budkowa, Warszawa 1978, s. 53.

11 Dotychczasowe badania historyków pozwalają wysunąć argument, iż za panowania Kazimierza I Odnowiciela na ziemie polskie sprowadzono duchowieństwo z diecezji leodyjskiej (Lotaryngia), chcąc odnowić struktury Kościoła w Polsce po kryzysie monarchii piastowskiej, na który przypadła reakcja pogańska. Z wątkiem prowansalskim jest z kolei związane opactwo św. Idziego w St Gilles, do którego pielgrzymowali m.in. Bolesław Krzywousty, palatyn Sieciech, Piotr Włostowic. Ponadto Prowansja znajdowała się na
} 
Agnieszka Teterycz-Puzio $\mathrm{w}$ recenzowanej monografii starała się w wyczerpujący sposób zarysować podejmowaną tematykę, co poświadcza przedstawiona baza źródłowa wykorzystana do napisania niniejszej pracy. Najważniejszymi źródłami do poznania historii uczestników wędrujących do Jerozolimy z ziem polskich okazały się przede wszystkim przewodniki pątników, dokumenty papieskie, tzw. supliki, relacje utrwalone atramentem w kronikach, rocznikach. Autorka korzystała również $\mathrm{z}$ ksiag miejskich ${ }^{12}$.

Układ treści w omawianej książce jest przejrzysty. Publikacja składa się z trzech większych części, które dzielą się na pomniejsze rozdziały. W części pierwszej Autorka przedstawiła ogólne informacje dotyczące podróżowania do Ziemi Świętej. W poszczególnych rozdziałach opisała warunki tychże podróży, motywy ich podejmowania, a także szlaki komunikacyjne. Jako najczęstsze powody udziału w krucjatach wskazała: przesłanki religijne (obrona wiary chrześcijańskiej, pielgrzymki pokutne, dziękczynne, odpusty), sławę rycerską łupy i wymianę handlową. Zwróciła także uwagę na rolę zakonów rycerskich oraz na związki franciszkanów z Ziemią Świętą. Wśród tych pierwszych nie pominęła najbardziej znanych Ubogich Rycerzy Chrystusa, zwanych powszechnie templariuszami. Pierwotnie bractwo, którego założycielem był rycerz z Francji Hugo z Payns, zostało uznane przez papieża podczas synodu w Troyes w 1128 r. za zakon i otrzymało regułę ${ }^{13}$. Starania te popierał sam Bernard z Clairvaux. W Ziemi Świętej templariusze posiadali na własność dwa domy. Kolejnym zakonem rycerskim, który zrodził się w okresie wypraw krzyżowych, byli joannici. W połowie XI stulecia wybudowali hospicjum w Jerozolimie, które udzielało wsparcia pątnikom w postaci noclegów

trasie szlaku pielgrzymkowego wiodącego do Ziemi Świętej. Por. M. Gładysz, Zapomniani krzyżowcy, s. 30-31.

12 Anonim zw. Gall, Kronika polska, tłum. R. Grodecki, wyd. 6, Wrocław 1989, ss. 185; Bullarium Poloniae, t. 2 i 3, przekł. J. Sułkowska-Kuraś, S. Kuraś, Rzym 1985-1988; J. Długosz, Roczniki czyli kroniki sławnego Królestwa Polskiego, Ks. 5-11, tłum. J. Mrukówna, Warszawa 2009; Kodeks Dyplomatyczny Katedry Krakowskiej św. Wacława, t. I, wyd. F. Piekosiński, Kraków 1874 [KDKK]; idem, Kodeks Dyplomatyczny Małopolski, t. I-II, Kraków 1876-1886 [KDMłp]; Kodeks Kuropatnickiego, Kodeks Lubinski, Kodeks Szamotulski, Kodeks Królewski, w: Monumenta Poloniae Historica, t. III, wyd. A. Bielowski, Lwów 1878; Kronika Jana z Czarnkowa, tłum. J. Żerbiłło, Kraków 1996; Kronika wielkopolska, przekł. K. Abgarowicz, Kraków 2010, ss. 233; Loca peregrinationis Terre Sancte. Czternastowieczny przewodnik po Ziemi Świętej, wyd. W. Mruk, Kraków 2005; Rocznik kompilowany krakowski, Rocznik miechowski, Rocznik Sędziwoja, Rocznik Traski, w: Monumenta Poloniae Historica, t. II, wyd. A. Bielowski, Lwów 1872; Księgi ławnicze krakowskie 1365-1376 i 1390-1397, wyd. S. Krzyżanowski, Kraków 1904; Księgi radzieckie kazimierskie, wyd. A. Chmiel, Kraków 1932; Opisanie podróży Mikołaja von Popplau rycerza rodem z Wrocławia, tłum. P. Radzikowski, Kraków 1996.

13 A. De la Croix, op. cit., s. 59-63. 
i pomocy medycznej. Misją joannitów stała się także obrona chrześcijan na szlakach pielgrzymich.

Jedną z ważniejszych ról A. Teterycz-Puzio przypisała franciszkanom. Początki ich obecności w Ziemi Świętej datuje się na 1217 r. Wówczas została powołana prowincja franciszkańska. Bracia Mniejsi pełnili funkcję przewodników po Ziemi Świętej dla napływających chrześcijan. W swych kościołach pouczali wiernych, jakich zasad mają przestrzegać, poruszając się po miejscach świętych. W szczególności regulamin pielgrzymkowy zakazywał kontaktu z muzułmanami oraz nakazywał szlachetnie urodzonym Europejczykom nie ujawniać swego statusu społecznego, gdyż mogłoby ich to narazić na porwanie dla okupu ${ }^{14}$. Ostatecznie istnienie i działalność kustodii jerozolimskiej Zakonu Braci Mniejszych zatwierdził papież Klemens VI w 1342 r. specjalnie wydanymi na tę okoliczność bullami: Gratias agimus oraz Nuper carissimae. Do kustodii należały klasztory przy Bazylice Grobu Bożego na Górze Syjon, przy Grobie Najświętszej Marii Panny w Dolinie Jozafata, w Grotach Agonii u stóp Góry Oliwnej.

Część druga, a zarazem najistotniejsza, odnosi się do polskich uczestników biorących udział w wyprawach do Ziemi Świętej między XII a XIII stuleciem. Autorka na wstępie podkreśliła, że nie zachowała się jakakolwiek relacja kronikarska bezpośrednio opisująca czyny rycerstwa polskiego podczas krucjat. Jednakże przetrwały próbę czasu lakoniczne zapiski źródłowe, na podstawie których można stwierdzić, iż między XII a XIII w. z ziem państwa Piastów wyprawiło się w odległą podróż na Bliski Wschód co najmniej pięciu Polaków.

Pierwszym poświadczonym w źródle uczestnikiem wypraw krzyżowych był niejaki „książę lechicki”, który wyruszył na II krucjatę w 1147 r. Wzmianka ta pochodzi z kroniki Jana Kinnamosa, z pochodzenia Greka, w której zrelacjonowano spotkanie wojsk cesarza Konrada III z oddziałami króla francuskiego Ludwika VII w Nikei. Dalej kronikarz opisał, że byli jeszcze dwaj władcy, którzy wiedli za sobą silną armię. Jeden pochodził z Czech, zaś drugi przewodził Lechitom, przy czym J. Kinnamos podkreślił, że plemię to sąsiadowało z zachodnimi Węgrami ${ }^{15}$. Na przestrzeni dziesięcioleci historycy wysnuwali różnorakie hipotezy, dywagując który z książąt polskich mógł uczestniczyć w II wyprawie krzyżowej. Sugerowano, że wspomnianym „księciem lechickim” był Władysław II Wygnaniec. Opowiedział się za tym m.in. Stanisław Korwin oraz Autorka recen-

14 Por. H. Manikowska, op. cit., s. 127-167.

15 Kronika została opublikowana w XIX w. pt. Ioannis Cinnami Epitome rerum ab Ioanne et Manuele Commenis gestarum, ad fidem codicis Vaticani recensuit A. Meineke, "Corpus Scriptorum Historiae Byzantinae", t. 26, Bonnae 1836. Autorka recenzowanej pracy powołuje się na tłumaczenie Mikołaja Gładysza. Por. M. Gładysz, Zapomniani krzyżowcy, s. 51. 
zowanej pracy ${ }^{16}$. W szczególności wysuwając argument, iż Władysław II, będąc na wygnaniu, znalazł schronienie na dworze cesarza Konrada III, z którym był spokrewniony poprzez małżeństwo z jego przyrodnią siostrą Agnieszką Babenberg. W kręgach władcy niemieckiego hasła krucjatowe były zapewne znane. Ponadto, składając hołd lenny cesarzowi niemieckiemu, polski książę miał wręcz powinność stawić się na zbrojną wyprawę u jego boku.

Z kolei Mikołaj Gładysz, nie negując powyższej hipotezy, wyraził jednak swoje zastrzeżenia odnośnie do utożsamiania Władysława II Wygnańca z utrwalonym na kartach greckiej kroniki „księciem lechickim” i bardziej opowiedział się za Henrykiem Sandomierskim. Wśród poważniejszych argumentów wysunął fakt, że książę miał możliwość wystawienia do wyprawy silnego militarnie hufca rycerzy oraz nie brał udziału w krucjacie przeciwko Słowianom Połabskim i Prusom zorganizowanej w 1147 r. przez swych braci ${ }^{17}$. Niestety daremnie doszukiwać się w rodzimych źródłach słuszności obu hipotez.

Pewny natomiast jest fakt, że książę Henryk Sandomierski udał się w 1154 r. do Ziemi Świętej, co poświadczają polskie roczniki, a najstarsza adnotacja pochodzi z Rocznika lubińskiego opartego najprawdopodobniej na zaginionym Roczniku Dawnym ${ }^{18}$. Wydarzenie to utrwaliły również inne źródła ${ }^{19}$. W późniejszych powiązano wyprawę księcia z jego fundacją klasztoru Joannitów w Zagości. Chociaż przekazy źródłowe podają rok 1154, Autorka recenzowanej pracy przesunęła datę wyprawy księcia na okolice połowy 1153 r., hipotetycznie wskazując, że Henryk Sandomierski mógł zbrojnie wesprzeć krzyżowców króla jerozolimskiego Baldwina III podczas bitwy pod Askalonem ${ }^{20}$. Częściowo hipotezę tę wcześniej przytoczył Mikołaj Gładysz, aczkolwiek przesunął początek podróży księcia sandomierskiego na jesień 1152 r. ${ }^{21}$ Warto podkreślić, że czas trwania podróży do Jerozolimy zajmował przeciętnie w jedną stronę drogą lądową ok. 4 miesięcy, następnie drogą morską maksymalnie od 4 do 6 tygodni ${ }^{22}$. W kręgu dysputy pozostaje także intencja, którą kierował się książę Henryk, wyprawiając się ze swoim orszakiem. Najbardziej zdaje się przeważać

16 S. Korwin, op. cit., s. 37; A. Teterycz-Puzio, Polscy krzyżowcy, s. 132.

17 M. Gładysz, Zapomniani krzyżowcy, s. 57-58.

18 Por. MPH II, s. 833-834, 875; MPH III, s. 157.

19 Katalog biskupów krakowskich, w: Monumenta Poloniae Historica, n.s., t. X, cz. 2, wyd. J. Szymański, s. 88-89; J. Długosz, Roczniki, Ks. 5, s. 64-65.

20 Pierwotnie miasto Aszkelon. Po zwycięstwie krzyżowców zwane Askalon i inkorporowane do Hrabstwa Jaffy. Por. T.F. Madden, op. cit., s. 80.

21 M. Gładysz, Zapomniani krzyżowcy, s. 103.

${ }^{22}$ Najbardziej powszechnie uczęszczanymi trasami były trakt wiodący przez Ruś oraz tzw. trakt bałkański. Por. A. Teterycz-Puzio, Henryk Sandomierski, s. 80. 
pogląd o motywie religijnym, bowiem książę był człowiekiem pobożnym, fundatorem kościoła. Kronikarz Długosz, przywołując pielgrzymkę księcia sandomierskiego, użył sformułowania, iż kierował się on sprawami wyższego rzędu, a także był gotów ponieść śmierć męczeńską za obronę wiary, jednak nie było mu to dane ${ }^{23}$. Agnieszka Teterycz-Puzio zwróciła również uwagę na przypisywanie Henrykowi Sandomierskiemu przywiezienia relikwii Krzyża Świętego do Polski i przekazania ich kolegiacie łęczyckiej. O ile u początków monarchii piastowskiej i kształtowania się organizacji kościelnej na ziemiach polskich nie odnajdujemy zbyt wielu śladów związanych z kultem Męki Pańskiej, o tyle w XIII stuleciu upowszechnił się on w kręgach dworu książęcego.

Do Jeruzalem pielgrzymował także Jaksa z Miechowa, komes i fundator miechowskiego klasztoru Zakonu Rycerskiego Grobu Bożego w Jerozolimie, zwanego na ziemiach polskich bożogrobcami, co poświadczają zapiski Rocznika Kapituty Krakowskiej oraz Rocznika miechowskiego ${ }^{24}$. Autorka zwróciła uwagę na dokument arcybiskupa Cezarei, niejakiego Aymara z końca XII w., w którym odnotowano fakt ufundowania w Miechowie klasztoru bożogrobców, a zarazem przywiezienia przez Jaksę świętych relikwii do dalekiego kraju, jakim była Polska ${ }^{25}$. Być może wspomniany Jaksa dwukrotnie wyprawił się do Ziemi Świętej, gdyż motywem jego podróży był złożony ślub fundacyjny w Jerozolimie względem bożogrobców $^{26}$. Badacze, w tym Autorka recenzowanej publikacji, zwrócili uwagę na materiał źródłowy, jakim są zachowane numizmaty. Na monetach kopanickich Jaksy dostrzec można symbolikę powiązaną z motywami krucjatowymi. Jednym $z$ nich jest gałąź palmowa, która w omawianym okresie oznaczała wypełnienie ślubów krucjatowych przez krzyżowca i pątnika.

XIII stulecie przyniosło zmiany w rozwoju idei krucjatowej. Papież Innocenty III, chcąc rozszerzyć w świadomości wiernych słuszność konieczności walki o władzę chrześcijan w Ziemi Świętej, zreformował ruch krucjatowy przez nawoływanie do powszechnej rekrutacji w szeregi organizowanej armii. Zatem kolejne apele papieskie trafiały nie tylko do szlachetnie urodzonych, lecz także do przedstawicieli innych stanów oraz docierały do Kościoła powszechnego. Stolica Apostolska zbierała specjalny podatek na rzecz przedsięwzięcia nowej krucjaty ${ }^{27}$.

${ }^{23}$ Por. J. Długosz, Roczniki, Ks. 5, s. 64-65.

24 MPH II, s. 882.

25 A.F. Grabski, op. cit., s. 114.

26 J. Rajman, Pielgrzym i fundator. Fundacje kościelne i pochodzenie księcia Jaksy, „Nasza Przeszłość" 1994, 82, s. 6-7.

27 Por. M. Gładysz, Zapomniani krzyżowcy, s. 144-147; T.F. Madden, op. cit., s. 119. 
V krucjata (1217-1221) przyniosła za sobą udział kolejnego tajemniczego milites Christi z ziem polskich, którego również trudno jest utożsamić z konkretnym księciem. Zagadkowa postać „dux Polonie” pojawiła się w liście króla węgierskiego Beli IV do niejakiego Lenstaha, syna rycerza - krzyżowca Bohmy, który miał wyprawić się do Ziemi Świętej z hufcem księcia polskiego. Agnieszka Teterycz-Puzio przywołała w swym wywodzie dotychczasowe hipotezy, m.in. postać Bronisława Włodarskiego, jak i już niejednokrotnie wspomnianego w niniejszym artykule Mikołaja Gładysza. Branymi pod uwagę kandydatami byli: Władysław Odonic, Henryk Pobożny, Kazimierz Opolski oraz Kazimierz II pomorski ${ }^{28}$. Dla Mikołaja Gładysza polskim krzyżowcem V krucjaty był Kazimierz Opolski, gdyż poślubił Bułgarkę, co mogłoby oznaczać, że swoją przyszłą małżonkę poznał, wracając szlakiem krucjatowym do kraju. Ponadto historyk ten zwrócił uwagę na bliskość przygraniczną księstwa opolskiego z Węgrami ${ }^{29}$. Hipoteza ta odbiega od powszechnie przyjętego stanowiska wśród wielu historyków, m.in. Stanisława A. Korwina czy Marii Starnawskiej, którzy utożsamiają postać „,dux Polonie" z Władysławem Odonicem. Autorka recenzowanej pracy jednakże nie opowiedziała się jednoznacznie po stronie którejś z owych hipotez. Niewątpliwie wskazała, iż drugim krzyżowcem we wspomnianym czasie, co ma potwierdzenie w źródłach, był Kazimierz II pomorski ${ }^{30}$.

W przypadku innych uczestników wypraw krzyżowych A. Teterycz-Puzio z ostrożnością rzetelnego badacza podkreśla, iż ogólnikowe wzmianki źródłowe nie potwierdzają czy dana persona faktycznie odbyła pielgrzymkę do Ziemi Świętej i walczyła w jej obronie ${ }^{31}$. Trzeba zaznaczyć, że znaczna część kandydatów składała śluby krucjatowe i otrzymywała zezwolenia papieskie na wyprawę, aczkolwiek często do Ziemi Świętej nie docierała. Warto też podkreślić, że takowe wyprawy stanowiły ogromne przedsięwzięcie finansowe i były bardzo niebezpieczne $\mathrm{z}$ uwagi na możliwe ataki ze strony rabusiów, piratów czy niewiernych.

Ostatnia część recenzowanej książki poświęcona została późnośredniowiecznym pielgrzymkom Polaków do Ziemi Świętej, które nabrały przede wszystkim wymiaru religijnego i stanowiły wyraz głębokiej po-

28 B. Włodarski, O udziale Polaków w wyprawie krzyżowej Andrzeja II w 1217 roku, „Kwartalnik Historyczny" 1971, 76, 1, s. 30-31.

29 M. Gładysz, Zapomniani krzyżowcy, s. 166.

30 Wyprawę księcia pomorskiego Kazimierza II do Ziemi Świętej odnotowują kroniki m.in. Jana Bugenhagena czy Tomasza Kantzova. Wedle kronikarzy książę miał wyruszyć na krucjatę w $1217 \mathrm{r}$. wraz ze swoim rycerstwem, powrócił w $1219 \mathrm{r}$. i zmarł prawdopodobnie na skutek ran odniesionych $\mathrm{w}$ walkach $\mathrm{z}$ innowiercami.

${ }^{31}$ Dla przykładu można wymienić domniemaną wyprawę: Wielisława Jerozolimskiego, niejakiego Dzierżka oraz Racibora, jednego z synów Mściwoja I, wielkorządcy Pomorza Gdańskiego. Por. A. Teterycz-Puzio, Polscy krzyżowcy, s. 157-160, 178-189. 
bożności. Oczywiście podejmowano także wyprawy w celu zaspokojenia ciekawości i żądzy wiedzy. Stąd Autorka przytoczyła informacje odnośnie do podróży uczonych ludzi Kościoła do Ziemi Świętej. Innymi motywami była wymiana handlowa, do której dążyli chociażby mieszczanie i kupcy śląscy. Na uwagę zasługują książęta pomorscy, z uwagi na to, że przejawiali największą aktywność pielgrzymkową do Jerozolimy w XIV i XV stuleciu $^{32}$. Część trzecią kończy rozdział dotyczący podróżników do Ziemi Świętej na przełomie XV i XVI w.

Warto jeszcze zwrócić uwagę na pewne mankamenty, które można dostrzec w recenzowanej pracy. Na stronie 23 Autorka napisała, iż rozwijał się zwłaszcza „kult drzewa krzyża”. W moim odczuciu określenie to jest nieco trywialne $\mathrm{w}$ odniesieniu do jednej z najcenniejszych relikwii, jaką był Krzyż Święty dla chrześcijan. Rażąco przykuwa uwagę treść:

Prosty rycerz pikardyjski Robert de Clari wyrażał szczerze wielki zachwyt nad bogactwem Konstantynopola, gdzie jest tyle bogactw, że taka ich ilość nie znalazłaby się $\mathrm{w}$ żadnym innym $\mathrm{z}$ czterdziestu najbogatszych miast świata razem wziętych, zaś piękno i przepych budowli trudno opisać słowami (kościół św. Zofii, złote wrota z wielkimi słoniami czy naturalnej wielkości figury kobiet) ${ }^{33}$.

Otóż świątynią, o której mowa, nie jest kościół św. Zofii, a kościół Hagia Sophia, co z greckiego oznacza „Mądrość Bożą". Na stronie 64 podano datę 1264 r., a powinno być 1364 r., nawiązując do uczty u Wierzynka. Innych nieścisłości nie dostrzegam.

Odpowiadając na pytania postawione we Wstępie niniejszego artykułu, należy uznać, że polscy krzyżowcy, udając się do Ziemi Świętej, kierowali się głównie motywami religijnymi. Docelowymi miejscami odwiedzanymi były: Bazylika Grobu Bożego, Betlejem, Góra Synaj, Ogród Oliwny. Niewątpliwie taka pielgrzymka zwiększała prestiż książąt pątników, aczkolwiek cenniejsze stawało się posiadanie relikwii świętych. Warto dodać, że oprócz licznych pamiątek polscy pielgrzymi adaptowali również na grunt polski specyfikę duchowości świętego miasta - Jerozolimy. Zaczęły powstawać pierwsze kalwarie, które służyły upamiętnieniu i celebracji Męki Pańskiej. Ponadto do Polski sprowadzono pierwsze zakony rycerskie, joannitów i bożogrobców.

32 Autorka starała się odtworzyć na podstawie zachowanych źródeł pielgrzymki Barnina III szczecińskiego, Warcisława VIII. Więcej o wyprawach książąt pomorskich: J. Podolska, Pielgrzymi polscy w Ziemi Świętej 1350-1540, „Peregrinus Cracoviensis” 1996, 4, s. 215223; J. Zadręka, Pielgrzymki ksiażąt pomorskich do Ziemi Świętej i Rzymu w latach 1392/1393 i 1406/1407, w: Rycerstwo Europy Środkowo-Wschodniej wobec idei krucjat, red. W. Peltz, J. Dudek, Zielona Góra 2002, s. 91-102.

33 A. Teterycz-Puzio, Polscy krzyżowcy, s. 42. 
Z kolei na pytanie czy recenzowana monografia wnosi jakieś nowe ustalenia odnośnie do tematyki wypraw krzyżowych i ich związków z Polską w rodzimej historiografii, wydaje się, że raczej nie. Agnieszka Teterycz-Puzio skupiła się bardziej na usystematyzowaniu dotychczasowego stanu badań nad poruszanym zagadnieniem. Mimo to trzeba jednocześnie pogratulować jej przemyślanej konstrukcji pracy, która dzięki swej przejrzystości sprawia, iż książkę czyta się z zaciekawieniem i przyjemnością.

Ewelina Kazienko

(Uniwersytet Papieski Jana Pawła II w Krakowie) https://orcid.org/0000-0001-5077-3106

\section{BIBLIOGRAFIA (REFERENCES)}

\section{Źródła}

Anonim zw. Gall, Kronika polska, tłum. R. Grodecki, Wrocław 1989.

Bullarium Poloniae, t. 2 i 3, wyd. J. Sułkowska-Kuraś, S. Kuraś, Rzym 1985-1988.

Długosz J., Roczniki czyli kroniki sławnego Królestwa Polskiego, tłum. J. Mrukówna, Ks. 5-10, Warszawa 2009.

Katalog biskupów krakowskich, w: Monumenta Poloniae Historica, n.s., t. X, cz. 2, wyd. J. Szymański, Warszawa 1974.

Kodeks Dyplomatyczny Katedry Krakowskiej św. Wactawa, t. I, wyd. F. Piekosiński, Kraków 1874.

Kodeks Dyplomatyczny Małopolski, t. I-II, wyd. F. Piekosiński, Kraków 1876-1886.

Kodeks Kuropatnickiego, Kodeks Lubiński, Kodeks Szamotulski, Kodeks Królewiecki, w: Monumenta Poloniae Historica, t. III, Lwów 1878.

Kronika Jana z Czarnkowa, tłum. J. Żerbiłło, Kraków 1996.

Kronika wielkopolska, tłum. K. Abgarowicz, Kraków 2010.

Księgi ławnicze krakowskie 1365-1376 i 1390-1397, wyd. S. Krzyżanowski, Kraków 1994.

Księgi radzieckie kazimierskie, wyd. A. Chmiel, Kraków 1932.

Rocznik kompilowany, Rocznik miechowski, Rocznik Sędziwoja, Rocznik Traski, w: Monumenta Poloniae Historica, t. II, wyd. A. Bielowski, Lwów 1872.

\section{Opracowania}

De la Croix A., Templariusze. W sercu wypraw krzyżowych, przekł. I. Kasperska, Poznań 2006.

Gładysz M., O zapomnianych polskich krzyżowcach - kilka uwag na marginesie wypraw jerozolimskich księcia Henryka Sandomierskiego i Jaksy z Miechowa, w: Ksiażęta, urzędnicy, złoczyńcy, red. B. Śliwiński, „,Gdańskie Studia z Dziejów Średniowiecza”, nr 6, Gdańsk 1999.

Gładysz M., Zapomniani krzyżowcy. Polska wobec ruchu krucjatowego w XII-XIII wieku, Warszawa 2002.

Grabski F.A., Polacy w opiniach obcych X-XIII w., Warszawa 1964.

Grygiel J., Jaksa z Miechowa i inni. Udział Polaków w wyprawach krzyżowych do Ziemi Świętej, w: Ziemia Miechowska w dziejach Polski. Dziedzictwo i perspektywy, red. A. Waśko, Kraków 2006, s. 11-22.

Haag M., Tragedia templariuszy: powstanie i upadek państwa krzyżowców, przekł. A. Bakowczan-Rzeszut, Kraków 2016. 
Korwin A.S., Stosunki Polski z Ziemia Święta, Warszawa 1958.

Madden F.T., Historia wypraw krzyżowych: nowe ujęcie, tłum. A. Czwojdrak, Kraków 2008.

Madden F.T., Krucjaty, tłum. M. Zwoliński, Warszawa 2007.

Manikowska H., Jerozolima - Rzym - Compostela. Wielkie pielgrzymowanie u schyłku średniowiecza, Wrocław 2008.

Michałowski R., Historia powszechna. Średniowiecze, Warszawa 2009.

Ohler N., Życie pielgrzymów w średniowieczu. Między modlitwa a przygoda, Kraków 2000.

Podolska J., Pielgrzymi polscy w Ziemi Świętej 1350-1540, „Peregrinus Cracoviensis” 1996, 4.

Rajman J., Pielgrzym i fundator. Fundacje kościelne i pochodzenie księcia Jaksy, „Nasza Przeszłość" 1994,82 , s. 5-34.

Teterycz-Puzio A., Henryk Sandomierski (1126-1133 - 18 X 1166), Kraków 2009.

Teterycz-Puzio A., Henryk Sandomierski. Polski krzyżowiec (1126/1133 - 18 X 1166), Kraków 2015.

Teterycz-Puzio A., Na rozstajnych drogach. Mazowsze a Małopolska w latach 1138-1313, Słupsk 2012.

Teterycz-Puzio A., Piastowskie księżne regentki (koniec XII w. - pocz. XIV w.). O utrzymanie władzy dla synów, Kraków 2016.

Teterycz-Puzio A., Polscy krzyżowcy. Fascynująca historia Polaków w wyprawach do Ziemi Świętej, Poznań 2017.

Teterycz-Puzio A., Urzędnicy sandomierscy w okresie rozbicia dzielnicowego - geneza, znaczenie, kompetencje, „Słupskie Studia Historyczne” 2000, 8. 